Adam Dyrda

\title{
Momosa pragmatyzm prawny: rzeczywiste granice teorii, rozsądne granice krytyki ${ }^{1}$
}

\section{Wprowadzenie}

O popularności pragmatyzmu prawnego (legal pragmatism) świadczy wiele czynników. Jednym z nich jest oczywista statystyka. Artykuł The path of the law $\mathrm{O}$. W. Holmesa ${ }^{2}$, uważany za tekst kanoniczny tego nurtu, jest obecnie trzecim najczęściej cytowanym $\mathrm{w}$ historii anglojęzycznym artykułem prawniczym (zgodnie z HeinOnline, dane z czerwca 2012 r.) ${ }^{3}$. Jednakże wiele spośród istniejących odniesień do pragmatyzmu prawnego ma charakter przede wszystkim krytyczny. W tym krótkim opracowaniu chciałbym zaledwie zwrócić uwagę na wartość pewnych typów krytyki pod adresem pragmatyzmu prawnego. Skupię się na tych, które cieszą się największą popularnością, aby wskazać, że krytyki te zwyczajnie chybiają celu, gdyż przypisują pragmatyzmowi cechy, których nie posiada, albo ganią go za błędy, których ten nigdy nie popełnił. $\mathrm{Z}$ kolei głównym powodem napisania tego artykułu jest (być może zupełnie subiektywne) spostrzeżenie autora, że od czasu do czasu jakiś złośliwy Momos wstępuje w niektórych teoretyków prawa i sprawia, że szukają oni pod byle pretekstem usterek, szukają niepotrzebnie dziury w całym ${ }^{4}$.

1 Za krytyczne uwagi do tego artykułu uprzejmie dziękuję B. Janikowi.

2 O. W. Holmes, The path of the law, „Harvard Law Review” 1897, vol. 10, no. 8.

3 F. R. Shapiro, M. Pearse, The most cited law review articles of all time, „Michigan Law Review" 2012, vol. 110, s. 1483-1520.

4 Notabene W. James pisze w Pragmatyzmie w następujący sposób o rozwijanej przez siebie metodzie filozoficznej: „Punktem, na który chciałbym zwrócić specjalnie waszą uwagę, jest rola dawnych prawd; niezdolność wytłumaczenia ich stanowi źródło bardzo wielu niesprawiedliwych zarzutów przeciwko pragmatyzmowi. Wpływ ich jest bezwzględnie przemożny. Lojalność względem nich stanowi pierwszą, najczęściej jedyną zasadę; gdyż najbardziej rozpowszechniony sposób traktowania zjawisk tak nowych, że wymagają poważnego przeobrażenia naszych postulatów, polega bądź na zupełnem ich ignorowaniu, bądź na wymyślaniu tym, którzy świadczą o nich" (W. James, Pragmatyzm, Warszawa 1911, s. 34-35). To stwierdzenie Jamesa niech zostanie uznane za motto niniejszego tekstu. 
Niniejszy tekst składa się z dwóch zasadniczych części. W pierwszej dokonuję krótkiej charakterystyki pragmatyzmu prawnego jako kierunku teoretycznoprawnego. W drugiej wskazuję krótko na podstawowe zarzuty, jakie są wysuwane pod adresem pragmatyzmu prawnego, aby wykazać, że przynajmniej niektóre z tych zarzutów są oparte na nieporozumieniu. Przy tym ostatnim zadaniu posłużę się taktyką, przy pomocy której w jednym ze swoich ostatnich artykułów T. Gizbert-Studnicki wykazał bezzasadność zarzutów wobec współczesnego pozytywizmu prawniczego ${ }^{5}$. Taktyka ta znajdzie doskonałe zastosowanie także w naszych rozważaniach. Jej zasadniczą zaletą jest to, że pozwala ujawnić cechy swoiste danej teorii na zasadzie kontrastu, tj. przez pryzmat zniekształceń dokonywanych przez nieprzychylnych krytyków (tzn. takich, którzy budują własny obraz danej teorii w naszym wypadku pragmatyzmu prawnego - nie stosując [albo wręcz wprost ją negując] podstawowej zasady krytyki, jakąjest tzw. principle of charity ${ }^{6}$ ). $\mathrm{W}$ drodze strukturalnej analogii do przywołanego tekstu T. Gizberta-Studnickiego, w którym za nieporozumienie uznaje się traktowanie pozytywizmu prawniczego jako teorii zajmującej się wyłącznie prawem pozytywnym przy zastosowaniu metody formalno-dogmatycznej (a więc skupiającej się wyłącznie na prymitywnych metodach interpretacji historycznych działań instytucji prawodawczych), w tym tekście zajmę się pragmatyzmem prawnym jako teorią posądzaną o coś dokładnie przeciwnego - a mianowicie oskarżaną o to, że nie bacząc na logiczną spójność doktryny prawniczej, pozwala sędziom stosować dowolne środki prospektywnie (pro futuro) w imię abstrakcyjnie określonego celu, jakim jest dobrobyt społeczny. Notabene, gdyby traktować pozytywizm i pragmatyzm wyłącznie tak, jak życzą sobie tego jego krytycy, trudno byłoby między tymi teoriami znaleźć jakiekolwiek punkty wspólne, gdyż pozytywizm byłby „teorią przeszłości”, a pragmatyzm „teorią przyszłości”. Tymczasem coraz częściej pojawiają się argumenty, że obie te teorie, nawet jeśli nie mają ze sobą wiele wspólnego, to przynajmniej nie pozostają w konflikcie, jeśli interpretować je życzliwie. Wrócę do tego wątku w podsumowaniu.

\section{Pragmatyzm filozoficzny i prawny}

Nie sposób w tak krótkim tekście przedstawić podstaw ruchu intelektualnego tak obszernego, jak pragmatyzm filozoficzny. Zamiast tego ograniczę się do wskazania kilku cech charakterystycznych filozofii pragmatyzmu, aby w dalszej kolejności scharakteryzować, równie oględnie, kierunek zwany pragmatyzmem prawnym?

5 T. Gizbert-Studnicki, Pozytywistyczny park jurajski, „Forum Prawnicze” 2013, nr 1 (15), s. 50-60.

6 Zgodnie z zasadą życzliwości daną teorię można poddać krytyce dopiero po dokonaniu możliwie najsilniejszej (najżyczliwszej) wykładni tej teorii. W przeciwnym wypadku istnieje poważne podejrzenie, że krytyka nie jest adekwatna, stanowiąc przez to raczej formę ,krytykanctwa”.

7 Dokładniejszą charakterystykę pragmatyzmu filozoficznego znajdzie Czytelnik w: T. Szubka, Neopragmatyzm, Toruń 2012. 
Podstawowe założenia filozoficzne pragmatyzmu można scharakteryzować następująco. Prawdę powiedziawszy, nieco paradoksalnie, pragmatyzm nie stanowi (i nie stanowił od samych swych początków) niczego nowego ${ }^{8}$. Pragmatyści zakładają ścisłe powiązanie twierdzeń filozoficznych (charakteryzujących się zawsze pewnym stopniem ogólności lub abstrakcyjności) z doświadczeniem i osiągnięciami nauk szczegółowych. Założenie to jest wymierzone przeciw przesadnym, przeintelektualizowanym i abstrakcyjnym koncepcjom metafizycznym. Twierdzi się tutaj, że rozdział praktyki i teorii - wbrew temu, co pisze np. J. M. Bocheński - jest w istocie „szkodliwym zabobonem” i że „czysta”, „abstrakcyjna”, oderwana od praktyki teoria nie ma sensu. W związku z porzuceniem możliwości przeprowadzenia linii granicznej między praktyką i teorią pozostaje także wiele innych założeń przyjmowanych przez myślicieli o pragmatycznym temperamencie: odrzucenie odróżnienia prawd a priori (transcendentalnych, nadrzędnych) oraz a posteriori (obserwacyjnych); a także odrzucenie absolutystycznej i zupełnej wizji rzeczywistości (W. James nazywa taki pogląd odkrywający gotową, statyczną i patrzącą jedynie w przeszłość teorię „racjonalizmem”) na rzecz idei, że rzeczywistość podlega ciągłemu stwarzaniu („reality [...] is still in the making”). To oznacza, że pragmatyzm w kontekście teoriopoznawczym stanowi wersję umiarkowanego sceptycyzmu (C. S. Peirce zarezerwował dla teoriopoznawczego pragmatyzmu nazwę „fallibilizm”). F. Schiller w swym wykładzie pt. Określenie pragmatyzmu i humanizmu z 1905 r. wskazał (podobnie jak W. James w Pragmatyzmie) na to, że wszelkie nowsze odmiany pragmatyzmu opierają się na swoistym zastosowaniu maksymy sformułowanej przez C. S. Peirce’a dla wyjaśniania znaczenia pojęć (tzw. „maksymy pragmatycznej” albo „zasady Peirce'a”10): „skoro twierdzenie jakieś rości pretensję do prawdziwości, jego następstwa powinny zawsze posłużyć do stwierdzenia zasadniczości tego roszczenia”, czyli że „o prawdziwości czyli wartości realnej twierdzenia decyduje to, co wynika z jego prawdziwości dla jakiegoś interesu ludzkiego, szczególnie zaś dla tego, do którego zostaje ono w bezpośrednim stosunku". Jednak poprzestanie na wzmiankach F. Schillera w tej kwestii mogłoby stanowić nadinterpretację, jeśli nie oddać głosu samemu C. S. Peirce'owi, który pisał w następujący sposób:

rozważmy, jakie to skutki, o których da się pomyśleć, że mają praktyczny wymiar, wiążemy myślowo z przedmiotem naszej koncepcji. Nasza koncepcja tych skutków jest zatem całą naszą koncepcją tego przedmiotu ${ }^{11}$.

${ }^{8}$ Nie bez powodu podtytuł zbioru wykładów W. Jamesa brzmi: Nowa nazwa dla niektórych dawnych sposobów myślenia.

9 J. M. I. Bocheński, Sto zabobonów, Kraków 1994, s. 127-128.

${ }^{10}$ W. M. Kozłowski, Wstęp, [w:] W. James, Pragmatyzm, s. XIX.

${ }^{11}$ Cyt. za: T. Szubka, op. cit., s. 14. 
Przyjęcie tej zasady pozwala określić prawdziwość jako coś, co ma „wyniki”, czyli następstwa (a prawda bez ,wyników” jest nonsensowna) ${ }^{12}$ dla kogoś i do czegoś (a więc w pewnym stopniu zrelatywizowana podmiotowo i przedmiotowo), mające „praktyczne lub dobre” znaczenie. W efekcie na gruncie tej zasady możliwa jest eliminacja teorii, które nie wiążą się z żadnymi wynikami w ogóle (spekulacje metafizyczne), a także możliwość identyfikacji ze sobą z pozoru różnych i odmiennie nazwanych teorii, gdy prowadzą one do jednakowych skutków (bo wtedy jedyna między teoriami różnica ma charakter czysto słowny). Niemniej, maksyma pragmatyczna wskazuje nam, że pragmatyzm stanowi rodzaj filozoficznej metody (a nie - doktryny!), która może zostać pogodzona $z$ rozmaitymi teoriami metafizycznymi pod warunkiem, że spełniają one pewne warunki minimalne.

Zasadniczo można wskazać hasłowo na następujące cechy pragmatyzmu: (a) odrzucenie absolutyzmu; (b) radykalny empiryzm; (c) instrumentalizm; (d) ewolucyjny wzrost wiedzy ${ }^{13}$. Na znaczenie (a) i (b) wskazałem już wyżej. Z kolei (c) oznacza, że prawdziwość przekonań ma instrumentalne znaczenie dla naszego życia. W. James wskazuje zresztą: „truth is whatever proves itself to be good in the way of belief”, dodając, że jest to ,an affair of leading”"14. Prawda (bądź „prawdziwość przekonań”) stanowi środek (instrument) do osiągania przez ludzi pożądanych przez nich celów, (które nigdy nie są określone z góry). Termin „instrumentalizm” pochodzi od J. Deweya, który wskazywał, że prawdziwe idee to takie, które działają w satysfakcjonujący sposób (work satisfactorily) i prowadzą do dobrych konsekwencji (good consequences) ${ }^{15}$. Pozostaje to w ścisłym związku z maksymą Pierce’a, jakkolwiek głębiej objaśnia jej sens, zważywszy na to, że pojęcie „satysfakcji” i „dobrych konsekwencji” nie ma znaczenia jedynie subiektywnego, osobistego, materialnego bądź emotywnego. Raczej chodzi tutaj o „satysfakcję intelektualną”, dobre konsekwencje jako zgodność interakcji przekonań (stwierdzeń) ze zjawiskami w obrębie życia eksperymentalnego. Stwierdzenia są prawdziwe w stopniu, w jakim spełniają (satisfy) nasz żywotny interes w posiadaniu takiej koncepcji rzeczywistości, która pozwala gromadzić różne przekonania - do siebie dopasowane, względem siebie spójne, logicznie konsystentne ${ }^{16}$. Stąd wniosek, że metoda pragmatyczna w swym pierwotnym sformułowaniu dotyczy rozjaśniania sensu nie wszystkich pojęć, a jedynie „pojęć intelektualnych", tzn. takich, które występują w argumentach dotyczących faktów

${ }^{12}$ W. M. Kozłowski, Wstęp, s. XIX.

${ }^{13}$ Por. D. Lind, The mismeasurement of legal pragmatism, „Washington University Jurisprudence Review" 2012, vol. 4, no. 2, s. 224 i n.

${ }^{14}$ Ibidem, s. 231.

${ }^{15}$ J. Dewey, Essays in experimental logic, [w:] L. A. Hickman, T. M. Alexander (eds), The Essential Dewey, vol. 2: Ethics, Logic, Psychology, Bloomington 1998, s. 90.

${ }^{16}$ D. Lind, op. cit., s. 232. 
obiektywnych ${ }^{17}$. Tworzenie siatek pojęciowych i przeprowadzanie racjonalnych badań ma znaczenie praktyczne, bowiem pozwala lepiej radzić sobie z rzeczywistością, do której opisania i zrozumienia służy. W tym sensie prawdziwe przekonania stanowią instrument do manipulowania otoczeniem.

Ostatnie ze wskazanych cech, ewolucyjny wzrost wiedzy (d), łączy się z założeniem o tym, że ,świat ciągle jest stwarzany”, a każda prawda ma prowizoryczny charakter, będąc przedmiotem weryfikacji, falsyfikacji lub zmiany (fallibilizm). Zakłada się przy tym, że z poznawczego punktu widzenia wszyscy jesteśmy konserwatystami. Stawiając czoła nowym faktom, zdobywając nowe przekonania, staramy się z dotychczasowego zbioru naszych przekonań utrzymać jak najwięcej. Pojęcia i idee nigdy nie są ustalone raz na zawsze, lecz są dynamiczne, przeobrażają się, stanowiąc ewoluujące interpretacje życia.

W rozmaity sposób interpretowano podstawowe idee pragmatyzmu. Przykładowo, W. James starał się poszerzyć działanie metody Peirce’a i zastosować ją do rozstrzygania wszelkich sporów filozoficznych. Dodatkowo, liczne, lecz wyrwane z kontekstu stwierdzenia W. Jamesa, że metoda ta wiąże się ściśle z pojęciem prawdy, która ,jest tylko środkiem w naszym sposobie myślenia, tak jak słuszność jest środkiem w naszym sposobie zachowania się"18 albo, że „prawdziwe są te idee, które potrafimy przyswoić, uprawomocnić, potwierdzić i zweryfikować", sugerują zdaniem niektórych, że mamy tu do czynienia $\mathrm{z}$ prostacką formą empiryzmu i weryfikacjonizmu, bądź też z nieuprawnionym utożsamieniem prawdy z użytecznością ${ }^{19}$. Tymczasem W. James nie odrzuca bezwzględnie prostej, realistycznej (korespondencyjnej) teorii prawdy, a jego przykłady pokazują jedynie, że stosowanie pojęcia „prawda” i „prawdziwość” wykracza poza takie proste użycie, a zatem świadczą na rzecz tezy, że pomimo pewnych jej zalet, nie należy przeceniać doniosłości tego typu koncepcji. Jak wskazuje C. Hookway, kluczem do właściwej interpretacji jest należyte zrozumienie pojęcia „zgadzania się przekonań z rzeczywistością”. Okazuje się, że należy przypisać W. Jamesowi pogląd, że

przekonanie zgadza się z rzeczywistością wówczas, gdy pozwala nam wejść w zadowalające relacje z naszym doświadczeniem; gdy pozwala usunąć anomalie, z którymi borykają się nasze istniejące przekonania i rozwiązać konkretne problemy życiowe ${ }^{20}$.

Dopasowanie nowych przekonań do ich istniejącego całokształtu (fitting of beliefs) ma tutaj kluczowe znaczenie.

${ }^{17}$ T. Szubka, op. cit., s. 15.

${ }^{18}$ W. James, Pragmatyzm, s. 123.

${ }^{19}$ T. Szubka, op. cit., s. 18.

${ }^{20}$ C. Hookway, William James "Pragmatism: A New Name for Some Old Ways of Thinking", [w:] J. Shand (ed.), Central Works of Philosophy, vol. 4: The Twentieth Century: Moore to Popper, Acumen-Chesham 2006, s. 64, cyt. za: T. Szubka, op. cit., s. 18. 
Wskazałem wyżej ogólnie na podstawowe tezy klasycznego pragmatyzmu, które rozwijali tacy filozofowie jak C. S. Peirce, W. James, F. Schiller, G. H. Mead. W nawiązaniu do nich swoje poglądy kształtowali kluczowi amerykańscy myśliciele pierwszej połowy XX w., tacy jak O. W. Holmes, T. Veblen, J. Dewey, J. H. Robinson. Poglądy tradycyjnych pragmatystów stanowią z kolei inspirację dla rozwoju neopragmatyzmu, kierunku o szczególnie analitycznym charakterze (jego przedstawiciele to m.in. W. V. Quine, S. Hook, M. G. White, R. Rorty, H. Putnam, R. Brandom), którzy inspirują myślicieli w rożnych dziedzinach także dzisiaj ${ }^{21}$.

Czym jest natomiast pragmatyzm prawny, którym się teraz zajmę? W największym uproszczeniu można określić go jako szeroki ruch, w ramach którego podstawowe idee pragmatyzmu są stosowane w kontekście prawoznawstwa. Podobnie jak pragmatyzm filozoficzny miał swoja genezę w sprzeciwie wobec wybujałej metafizyki, tak pragmatyzm prawny stanowi sprzeciw wobec klasycznej wizji prawoznawstwa, zgodnie z którą fakty prawotwórcze i metody interpretacji (głównie analiza precedensu w stylu C. C. Langdella, tzw. casebook method oraz argument $z$ analogii) mają charakter uniwersalny. Pragmatyści prawni uznają, że dokonując analiz prawnych, należy uwzględnić znacznie szerszy zakres danych i czynników, aby zrozumieć prawo jako instytucję działającą w szerokim kontekście społecznym. Argumenty filozoficznego pragmatyzmu przeciwko wszelkim racjonalizatorskim i uniwersalizującym tendencjom w nauce są przez pragmatystów prawnych stosowane wprost. W szczególności argumentują oni przeciwko wyłącznemu stosowaniu metod dedukcyjnych w prawoznawstwie. „Zły człowiek” (bad man) O. W. Holmesa „ni w ząb nie troszczy się o dedukcję i aksjomaty, lecz chce po prostu wiedzieć, co sądy stanu Massachusetts robić będą"22. Co więcej, prawo nie stanowi, jak wyobrażają to sobie uniwersalne teorie, ,jakiegoś transcendentnego majaka na niebie" (brooding omnipresence in the $s k y)^{23}$, lecz ma przede wszystkim praktyczne znaczenie, a zadaniem jurysty-pragmatysty jest wskazanie czynników, które wpływają nie tylko praktycznie na proces podejmowania decyzji, lecz także, pozostając z tym w ścisłym związku, wskazują, dlaczego prawo stwarza „praktyczną różnicę” w rozumowaniach podmiotów. Te dwie ostatnie kwestie pokazują, że dzisiaj trudno uprawiać teorię prawa bez przynajmniej ogólnej znajomości myśli pragmatycznej. W tym sensie następujące stwierdzenie B. Cardozo, autora pierwszej dopracowanej (wzorcowej!) koncepcji pragmatyzmu na gruncie prawnym, pozostaje aktualne:

${ }^{21}$ Patrz: T. Szubka, op. cit., passim.

${ }_{22}$ Por. O. W. Holmes, op. cit., passim.

${ }^{23}$ Dwa popularne epigramy Holmesa brzmią: „The life of the law has not been logic; it has been experience” oraz „The common law is not a brooding omnipresence in the sky”. Ten ostatni pochodzi z jego zdania odrębnego do wyroku w sprawie Southern Pacific Company przeciwko Jensen, 244 U.S. 205, 222 (1917). 
„[pragmatism is] profoundly affecting the developement of juristic thought" 24 . Krótka charakterystyka podejścia B. Cardozo pozwoli uchwycić główne cechy pragmatyzmu prawnego.

Przede wszystkim, zdaniem sędziego Cardozo, reguły prawne nie posiadają statusu absolutnego (nie sa, jak wskazywał powoływany przez niego M. Smith, „dojrzałymi owocami gotowymi do zebrania z [prawnego] drzewa" - [final truths] full-blossomed from the trees), a zamiast tego stanowią, jak określa to za J. Deweyem, swoiste "hipotezy robocze” (working hypotheses) ${ }^{25}$. Model dedukcyjny stosowania prawa zostaje wprost odrzucony na rzecz modelu indukcyjnego, a proces podejmowania decyzji przez sędziego polega na „ciagłym wydobywaniu organicznie zespolonych reguł i zasad w toku pragmatycznego procesu decydowania sprawa-po-sprawie (pragmatic process of case-by-case decision-making)" ${ }^{26}$. Przeprowadzenie tego procesu wymaga od sędziego nie tylko doświadczenia, lecz także myślenia eksperymentalnego (experimental mindset). Każda kolejna sprawa stanowi nowy eksperyment, podejmowany w kontekście szczególnych okoliczności, gdzie istniejące hipotezy prawne są testowane i ponownie rozważane. Stąd ,podstawy prawa”, określane jednoznacznie i uniwersalnie przez racjonalistycznych teoretyków prawa (w ich „wielkich laboratoriach prawnych”), są de facto przedmiotem ciągłego testu i mogą być poddane zmianom. Ogólnym testem dla akceptacji i zastosowania określonych zasad prawnych jest spójne i wydajne oddziaływanie na rzecz dobrobytu społecznego. Z kolei te zasady, które nie działają (do not work well), albo wręcz stwarzają niesprawiedliwość (work injustice), są ponownie rozważone i w końcu - odrzucone ${ }^{27}$. W tym miejscu fallibilistyczne założenia pragmatyzmu filozoficznego - dopasowanie do systemu istniejących i spełniających swoją rolę, konserwatywnie zachowywanych przekonań (którymi w przypadku pragmatyzmu prawnego są względy tradycji i twierdzenia dopuszczalne w granicach systemu prawa) - sprawdzają się. System prawa to powiązana organicznie całość, oparta na tradycji i historii, które wyznaczają granice dopuszczalnych argumentów. Jednakże te, jak je określa B. Cardozo, interstices, wyznaczają jedynie „ściany prawnego laboratorium”, obowiązują w ramach - jak byśmy dzisiaj powiedzieli - obowiązującego paradygmatu uprawiania nauki i powiązanego z tym sposobu testowania hipotez roboczych. Ściany laboratorium wyznaczają przestrzeń sędziowskiego działania, czyli dyskrecji, choć w większości prostych (oczywistych) przypadków prawo bardzo wąsko zakreśla przestrzeń swobody. Niektóre przypadki prawne wymagają jednak wyjścia naprzeciw nowym okolicznościom i sprawdzenia w nich dotychczas akceptowanych hipotez. Ten twórczy element sądzenia (creative element of judging) odgrywa

\footnotetext{
${ }^{24}$ Cyt. za: D. Lind, op. cit., s. 252.

${ }^{25}$ B. Cardozo, The Nature of the Judicial Process, New Haven 1921, s. 103.

${ }^{26}$ D. Lind, op. cit., s. 253.

${ }^{27}$ Por. ibidem.
} 
podstawową rolę, o ile funkcją - co jest wyrazem charakterystycznego dla pragmatystów funkcjonalizmu - którą ma spełniać sędzia, jest dążenie do wydania decyzji zgodnej z fundamentalnym interesem społecznym, utożsamianym z pojęciami „sprawiedliwości społecznej” i „dobrobytu społecznego" ${ }^{28}$. Niemniej, ten twórczy element pojawia się tylko w wyraźnie określonych sytuacjach dla praktyki prawniczej, tzn. takich, w których instytucje sądowe muszą rozważyć przypadki wysoce kłopotliwe, w których odwołanie się do wielu kontekstualnych czynników społecznych, poza logiką, tradycją czy historią, może mieć znaczenie dla wydania decyzji (kontekstualizm).

W wyżej opisanym sensie pragmatyzm prawny B. Cardozo odwołuje się do pojęcia „skutków” czy „konsekwencji” (consequences) decyzji. Skutki te są, $\mathrm{z}$ punktu widzenia dobrze skonstruowanej decyzji, tożsame $\mathrm{z}$ realizacją pożądanych społecznie wartości lub celów. Niemniej, sama metoda pragmatyczna, uwidaczniająca się w dążeniu do ograniczenia zakresu dyskrecji sędziowskiej przy pomocy wymogu rozważenia wartości społecznych i dostosowania decyzji do zmieniających się potrzeb społecznych, nie ma nic wspólnego z realizacją jakiegokolwiek z góry określonego standardu celowościowego (wtedy byłaby to zresztą teoria substancjalna, a nie jedynie metoda). Co więcej, chociaż społeczna wartość danej reguły prawnej uzasadnia jej zastosowanie, to nie należy, przed czym przestrzegał B. Cardozo, redukować rozumowania sędziego do krótkofalowych, subiektywnie postrzeganych korzyści bądź oczekiwań nastąpienia takich skutków. Stwierdził on wprost: „I do not mean [...] that judges are commissioned to sed aside existing rules at pleasure in favor of any other set of rules which they may hold to be expedient or wise" ${ }^{29}$. Orzekanie nie może być kwestia kaprysu! Decyzja o twórczym charakterze może się pojawić jedynie w sytuacji luk w prawie bądź nieokreśloności (indeterminacy), lecz zawsze w granicach wyznaczonych przez istniejące „laboratorium prawne” i panujący w nim „paradygmat”. W tak określonych granicach sędzia jest rzeczywiście wolny, lecz - jeśli rozważyć tę kwestię w najwyższej ogólności - jego wolność nie ma charakteru absolutnego. Ta idea B. Cardozo, charakterystyczna dla myślenia pragmatycznego w ogóle, pojawia się dzisiaj także w rozważaniach wielu innych teoretyków prawa, pod rozmaitymi postaciami. Przykładowo, podobny sposób myślenia stoi u podstaw idei A. Marmora, że reguły prawne wraz z właściwą im normatywnością są współokreślane (underdetermined) przez głębsze konwencje właściwe dla danej kultury. Wydaje się także, że omawiana przez J. Wróblewskiego idea „sądów systemowo zrelatywizowanych” pozostaje w ścisłym związku z pragmatycznym założeniem o ograniczeniu obowiązywania pewnych sądów względem pewnych kryteriów (jakkolwiek kryteria pragmatyczne są szeroko i jedynie

${ }^{28}$ B. Cardozo pisał: ,[judges] shape [their] judgment in obedience to the fundamental interest of society" (B. Cardozo, op. cit., s. 140).

${ }^{29}$ Ibidem, s. 66-67; por. D. Lind, op. cit., s. 257. 
formalnie zakrojone). Co więcej, związek z doktryną tzw. „,władzy ukierunkowanej" (directed power), którą postuluje np. J. Raz, jest nadto oczywisty. W wersji zaproponowanej przez B. Cardozo ograniczenia te (o charakterze logicznym, zwyczajowym, tradycyjnym, historycznym, społecznym, sprawiedliwościowym) zostają zrozumiane przez sędziego poprzez zdobywane przez niego doświadczenia. W tym ujęciu sędzia nie skupia się na prostych, możliwych do skalkulowania i osiągnięcia, krótkoterminowych profitach, ale stara się wydać decyzję w oparciu o najlepsze możliwe rozumienie tego, co jest w interesie społecznym. Skutki, o jakie tutaj chodzi, to nie (a przynajmniej nie w pierwszym rzędzie) rzeczywiste i bezpośrednie skutki decyzji sędziego. Skutki decyzji sędziego są natomiast oceniane z perspektywy ich zgodności z całokształtem wcześniej akceptowanych przekonań, co ma gwarantować jednolitość i bezstronność prawa (chodzi o dopasowanie przekonań - fitting of beliefs, jak to określał James) ${ }^{30}$.

Ta krótka charakterystyka pragmatyzmu B. Cardozo ukazuje, jak głęboko powiązany jest jego pragmatyzm prawny z pragmatyzmem filozoficznym. Stanowi on wyraz anty-absolutyzmu, empiryzmu, instrumentalizmu i fallibilizmu, związanego z przekonaniem o ewolucyjnym rozwoju wiedzy prawnej. Te cechy określają metodę pragmatyczną, która nie odwołuje się do prostych do przewidzenia konsekwencji decyzji, lecz ma przede wszystkim znaczenie teorio-poznawcze. Pozwala w jasny sposób wykluczyć z procesu podejmowania decyzji te racje i argumenty, których konsekwencje nie mogłyby zostać uznane w świetle zbioru utrwalonych standardów oceny (hipotez roboczych). Zmiana paradygmatu, jakkolwiek możliwa, jest w takich okolicznościach bardzo trudna, wymaga bowiem odrzucenia znacznej liczby takich hipotez. Ostatecznym, lecz bardzo ogólnikowym celem działania sędziego, jest osiągnięcie ideału sprawiedliwości społecznej. W trudnych przypadkach musi on abstrahować od konkretnych argumentów i wznieść się na poziom ogólności pozwalający rozwiązać te wątpliwości $\mathrm{w}$ zgodzie $\mathrm{z}$ tak zakreślonym celem. Zdolność sędziego do wykonania tego zadania będzie zależeć od jego doświadczenia. Niemniej, sędzia nie odwołuje się tutaj do konsekwencji czy celów jednoznacznie określonych - raczej odwołanie do nich ma charakter podobny, jak w imperatywie kategorycznym I. Kanta i przez to równie „formalne” znaczenie. Każda kolejna decyzja sędziowska stanowi pozytywną weryfikację istniejących hipotez, w przeciwnym razie byłaby nie do przyjęcia, albo wręcz niezrozumiała ze społeczno-kulturowego punktu widzenia. Z kolei krótkoterminowe cele-konsekwencje mają znaczenie, pod warunkiem wszakże, iż takie znaczenie jest zgodne z interesem społecznym.

Podsumowując powyższe rozważania, warto wskazać, że takie przedstawienie pragmatyzmu prawnego, pozostające w zgodzie z jego filozoficznym rodowodem, sprawia, iż pragmatyzm prawny nie jest pełnoprawną teorią prawa

${ }^{30}$ D. Lind, op. cit., s. 258 i n. 
(full-fledged theory of law) w sensie, jaki temu terminowi przypisują wspó1czesne teorie analityczne. Nie stanowi on bowiem w żadnym razie teorii, która dąży do odkrycia „istoty”, „esencji” czy „natury” prawa, więc tym bardziej nie stanowi on spójnej teorii, która dąży do przedstawienia ${ }^{31}$ pojęcia prawa (the concept of law). Ta kwestia jest bardzo istotna, ponieważ większość klasycznych zarzutów wobec pragmatyzmu prawnego (którego jedną z wersji są rozmaite postacie amerykańskiego realizmu prawnego), np. te formułowane przez H. L. A. Harta w Pojęciu prawa ${ }^{32}$ i przez podążających jego tropem pozytywistów, oparte są na założeniu, że pragmatyści (jak O. W. Holmes Jr czy B. Cardozo) dążyli do przedstawienia jakiejś teorii dotyczącej pojęcia prawa. Na ten błąd, generujący niepotrzebnie liczne, zupełnie nietrafione zarzuty, wskazał już przed laty M. G. White, broniąc O. W. Holmesa tymi słowy:

Whether those who hold that statues, reports, and treatises themselves constitute the law have more than a trivial verbal quarrel with Holmes is a nice question. It is customary to construe the debate between legal realists and their more traditional opponents as one between rival definitions of "the same concept", between competing attempts to arrive at the "essence of law", but this is a doubtful construal of the controversy ${ }^{33}$.

Pragmatyzm nie zmierza do przedstawienia żadnej uniwersalnej koncepcji prawa, jakiej poszukują przedstawiciele tzw. general jurisprudence. Jego ambicje są znacznie bardziej praktyczne, a twierdzenia znacznie bardziej płytkie. Niemniej, właśnie jako takie czasami mogą stanowić jego największy atut, a minimalistyczny program, ograniczający się do metody, pozwala pogodzić go, przynajmniej w pewnym zakresie, z teoriami, które mają znacznie szersze ambicje.

\section{Zarzuty}

Spośród wielu oskarżeń pod adresem pragmatyzmu prawnego ${ }^{34}$ wskazać można przykładowo na następujące: pragmatyzm prawny to „anty-teoretyczna” (P. S. Atiyah) 35 i „sceptyczna jurysprudencja” (sceptical jurisprudence - R. Dworkin) ${ }^{36}$, która dewastuje mozolnie wypracowywane przez teoretyków

${ }^{31} \mathrm{~W}$ jakim zakresie to „przedstawienie” stanowi rezultat procesu opisu, a w jakim opiera się na twórczych bądź wartościujących rozstrzygnięciach badacza - jest kwestią otwartą i dyskusyjną. Dość powiedzieć, że ten problem stoi u podstaw wielu kluczowych podziałów teoretycznych we współczesnej analitycznej filozofii prawa.

${ }^{32}$ H. L. A. Hart, The Concept of Law, 3rd Edition, Oxford 2013, s. 136-147.

${ }^{33}$ M. G. White, Social Thought in America. The Revolt Against Formalism, Oxford 1976, s. 62-63.

${ }^{34}$ Dokładniejsze wyliczenie zarzutów pod adresem pragmatyzmu prawnego znajdzie Czytelnik w: D. Lind, op. cit., s. 213-268.

${ }^{35}$ P. S. Atiyah, Pragmatism and Theory in English Law, London 1987.

${ }^{36}$ R. Dworkin, Law's Empire, Cambridge-London 1986, s. 95, 151, 160. 
prawa struktury rozumowań prawniczych $\left(\mathrm{R}\right.$. Dworkin ${ }^{37}, \mathrm{~B}$. Tamanaha $\left.{ }^{38}\right)$ i nie opiera się na żadnej głębszej teorii filozoficznej, będąc otwartą na manipulacje i instrumentalne użycie względem dowolnych celów. Jednym z najpoważniejszych zarzutów pod adresem pragmatyzmu prawnego jest sformułowana przez D. Lubana teza, że stanowi on oportunistyczny, zorientowany jedynie na rezultaty (result-orineted) punkt widzenia, który nastawiony jest na dobrobyt społeczeństwa, a nie na „spójność i czystość" prawa ${ }^{39}$. W podobny sposób argumentuje R. Dworkin, dla którego pragmatyzm prawny stanowi takie podejście do orzekania, zgodnie z którym sędzia powinien zawsze decydować w oparciu o przesłanki prospektywne, zakładając swoisty konsekwencjonalizm ${ }^{40}$. Spośród wskazanych zarzutów to właśnie zarzut konsekwencjonalizmu, wyłącznego ukierunkowania się na rezultaty, stanowi argument najpoważniejszy ${ }^{41}$.

Czym jest w takim razie „myślenie zorientowane na rezultaty” (result-oriented thinking)? Tego typu myślenie zmierza do wydania sądu dotyczącego tego, czy dany sposób działania prowadzi do skutków (konsekwencji), które spełniają (bądź nie) pewne z góry określone i niezależne od samego działania kryteria oceny tego działania. Sztandarowym przykładem jest klasyczny utylitaryzm, który wiąże pozytywną ocenę danego czynu wyłącznie z „dobrymi konsekwencjami”, którymi on skutkuje (pomijam tutaj liczne, a szeroko dyskutowane problemy ze sposobem zastosowania kryteriów utylitarystycznych ${ }^{42}$ ).

Krytyki D. Lubana i R. Dworkina już z metodologicznego punktu widzenia rodzą dwojaki problem. Po pierwsze, są one bardzo ogólne i w zasadzie nie obejmują niczego poza tym, co przytoczono wyżej (żaden z nich właściwie nie przywołuje głębszych argumentów na poparcie swoich generalnych tez). Po drugie, autorzy ci nie podają wskazówek co do tego, o poglądy jakich pragmatystów dokładnie im chodził ${ }^{43}$. Jak sądzę, operują oni najwyraźniej mglistym i potocznym

${ }^{37}$ R. Dworkin, Justice in Robes, Cambridge-London 2006, s. 21-24, 36-28; idem, Law's Empire, s. 151-164.

${ }^{38}$ B. Z. Tamanaha, Law as Means to an End: Threat to the Rule of Law, Cambridge 2006, s. $121-130$.

39 „Legal pragmatism is result-oriented or instrumental. Its focus is the well-being of the community, not the purity or integrity of legal doctrine" (D. Luban, What's pragmatic about legal pragmatism?, „Cardozo Law Review” 1996, vol. 18, s. 43).

${ }^{40}$ Dworkin wskazuje: ,[p]ragmatism holds that judges should always decide the cases before them in a forward-looking, consequentialist style" (R. Dworkin, Justice..., s. 21).

${ }^{41}$ Por. D. Lind, op. cit., s. 216, przyp. 19 i cytowana tam literatura.

${ }^{42}$ Podstawowa wątpliwość dotycząca tego, jaki charakter ma „dobro” („,dobre konsekwencje”), o których piszą utylitaryści, pozwala wyróżnić np. utylitaryzm preferencjonalistyczny (odwołujący się do ważenia indywidualnych preferencji), utylitaryzm hedonistyczny (gdzie dobre konsekwencje są utożsamione z przyjemnością) czy utylitaryzm eudajmonistyczny (gdzie dobre konsekwencje wiążą się ze szczęśliwością); inny podział obejmuje utylitaryzm reguł i utylitaryzm czynów. Już tylko te dwa podziały wywołują na gruncie współczesnej etyki utylitarystycznej wiele kontrowersji.

${ }^{43}$ D. Lind, op. cit., s. 266. 
rozumieniem pragmatyzmu jako „instrumentalizmu”, który był przedmiotem tak wielu niezasłużonych krytyk już przed II wojną światową (np. Krytyki instrumentalnego rozumu $\mathrm{M}$. Horkheimera, który sprowadza pragmatyzm właśnie do prostego rozumowania „z celów na środki”, choć gdyby lepiej zrozumiał podstawy tej doktryny, z pewnością sam zaakceptowałby pewne argumenty krytyczne wysuwane przez pragmatystów pod adresem określonych instytucji społecznych). Zarzut konsekwencjonalizmu nie jest więc podparty dostatecznymi dowodami i w tym sensie nie jest dobrze ugruntowany ${ }^{44}$. Lecz, co gorsza, zarzut ten zwyczajne chybia celu.

Z pewnością przywołana argumentacja nie odnosi się do idei „konsekwencji” obecnej w ujęciu pragmatyzmu prawnego B. Cardozo. Zarzut ukierunkowania na rezultaty nie ma tu $\mathrm{w}$ ogóle zastosowania, ponieważ przypisywałby sędziemu Cardozo wręcz absurdalną wizję adjudykacji. W końcu krytycy oskarżają pragmatyzm o to, że oddaje się sztuczkom (trickery) i wątpliwemu, prostackiemu eksperymentalizmowi (crude experimentalism), a także porzucaniu idei spójności logicznej i historycznej na rzecz instrumentalizmu, pozwalającego uzasadnić dowolną decyzję poprzez uznanie, że stanowi ona konieczny środek do osiągnięcia określonych celów społecznych. Jak dalekie jest to od prawdy w przypadku sędziego Cardozo, to Czytelnik z pewnością już sam zdążył zauważyć. B. Cardozo, jeśli powtórzyć argumentację przedstawioną wyżej, nie zgadzał się na prostą redukcję rozumowania sędziego do krótkofalowych, subiektywnie postrzeganych korzyści bądź oczekiwań nastąpienia jakichś skutków. Samo zaś odwołanie się do pojęcia konsekwencji społecznych nie świadczy jeszcze o przyjęciu konsekwencjonalizmu w rozumieniu, jakie temu terminowi zdają się przypisywać D. Luban i R. Dworkin. W pewnym istotnym sensie każda licząca się teoria prawa (jusnaturalizm, pozytywizm, integryzm itp.) rozważa prawo jako instytucję ukierunkowaną na jakiś cel i mającą jakieś konsekwencje, co jeszcze samo nie sprawia, że teorie te mają charakter teorii konsekwencjonalistycznych. Co do pozostałych zarzutów, to mają one znaczenie erystyczne, bowiem pragmatyzm w żadnym razie nie pochwala „dowolności” decyzji, a raczej stara się wskazać granice praktycznego zastosowania reguł poprzez odwołanie do stojącej u podstaw budowy społeczeństwa idei dobrobytu. Idea ta stanowi zaledwie ogólne, regulatywne kryterium, od którego wychodząc, sędzia, w toku swej praktyki orzeczniczej, winien zdobywać jak najszersze doświadczenie, testując posiadane „hipotezy robocze”. W żadnym razie nie stanowi to oszustwa, którym jest raczej nierzetelne referowanie poglądów innych po to, by wzmocnić blask własnych twierdzeń. Z kolei fallibilizm wraz z ideą ewolucyjnego wzrostu wiedzy zakłada implicite, że zbiór posiadanych przekonań jest zbiorem uporządkowanym i logicznie spójnym. Zarzut braku spójności zatem także upada.

${ }^{44}$ W Imperium prawa R. Dworkina znajduje się dość rozległa krytyka pragmatyzmu prawnego, ale ze świecą szukać tam jakiegoś przypisu! 
Wskazane uwagi krytyków, w świetle opisanej wyżej idei pragmatyzmu prawnego jako opartej na pragmatyzmie filozoficznym, pokazują, że atakują oni coś innego. Być może mają oni na myśli jakąś inną teorię o nazwie „pragmatyzm". Niemniej, nie jest to w żadnym razie teoria, która opiera się na tym, co pod pojęciem pragmatyzmu rozumieli tacy pragmatyści prawni, jak B. Cardozo czy O. W. Holmes, albo nawet J. Dewey. Rozumienie pragmatyzmu prawnego przez krytyków jest bardzo uproszczone, jeśli nie prostackie. Przypomina to argumenty wysuwane pod adresem innych teorii przez nieprzychylnych im krytyków. O argumentach przeciwko pozytywizmowi wspomniałem na początku, ale analogicznych sposobów krytyki można by odnaleźć bez liku. Swego czasu amerykański realizm prawniczy, będący w pewnym sensie rozwinięciem istotnych wątków pragmatycznych, był oskarżany o to, że jest ,prawoznawstwem śniadaniowym" (jurisprudence by breakfast). Tego typu argumenty są zupełnie niezasadne, lecz ze względu na lokucyjną siłę etykiety, stanowiącą karykaturę lub dowcip, przenikają do powszechnej świadomości. Jest jednak rzeczą dość przykrą, że poważni autorzy, jak w naszym wypadku R. Dworkin albo D. Luban, traktują takie dowcipy poważnie. Taka postawa pomnaża tylko problemy pojęciowe, pozwalając rażącym nieporozumieniom trwale się zadomowić.

\section{Podsumowanie}

Na koniec warto powtórzyć jeszcze za M. G. White'em, jaki cel przyświecał pierwszemu naczelnemu amerykańskiemu pragmatyście prawnemu, O. W. Holmesowi, a który można przypisać właściwie wszystkim zidentyfikowanym pragmatystom prawnym. Celem pragmatyzmu prawnego nie jest wydobycie „bezużytecznej kwintesencji wszystkich systemów prawnych” (useless quintessence of all legal systems), lecz raczej „rzetelne przedstawienie anatomii konkretnego porządku prawnego" (an accurate anatomy of one) ${ }^{45}$. To jest powód, dla którego pragmatyzm prawny może zostać pogodzony z innymi teoriami prawa, które starają się powiedzieć to, czego sam pragmatyzm nie mówi, bądź wobec czego pozostaje on sceptyczny.

Niezrozumienie tego prostego faktu stanowi przyczynę pojawienia się wielu dramatycznych teoretycznoprawnych humbugów, takich jak choćby krytyka przeprowadzona przez H. L. A. Harta pod adresem amerykańskiego realizmu (na której bezzasadność wskazuje B. Leiter) ${ }^{46}$. Jeśli stosować zasadę życzliwości w interpretacji teorii w sposób rzetelny, okaże się szybko, że teorie - w tym

${ }^{45}$ Por. M. White, The Philosophy of Culture: The Scope of Holistic Pragmatism, PrincetonOxford 2002, s. 130.

${ }^{46}$ Por. B. Leiter, Legal realisms, old and new, „Valparaiso University Law Review” 2013 („Seegers Lecture in Jurisprudence” 2012), a także: idem, Legal realism and legal positivism recnosidered, „Ethics” 2001, vol. 111, no. 2, s. 278-301. 
wypadku pozytywizm, który nie stanowi wcale „mechanicznej jurysprudencji przeszłości" (tj. odwołującej się li tylko do faktów przeszłych) oraz pragmatyzm, który nie jest tylko „teorią przyszłych konsekwencji” - pomimo pewnych istotnych różnic mają jakieś punkty wspólne. $Z$ tego powodu za własną hipotezę roboczą uznaję stwierdzenie, że można być jednocześnie pragmatystą i pozytywistą prawniczym, nie popadając jednak w teoretycznoprawną schizofrenię. Weryfikacji tej hipotezy poświęcę najbliższą przyszłośćc ${ }^{77}$.

Wyjaśnienie ukazanych wyżej spraw, pomimo lakonicznej formy, pozwala ujawnić niepoważne oblicze niektórych krytyków pragmatyzmu. Oczywiste jest, że mechanizm użyty w tym opracowaniu do obrony pragmatyzmu może mieć i z pewnością mieć będzie szersze zastosowanie. Tu, tak jak i w innych przypadkach, gdy fałszywa, lecz kusząca maska opadnie, ukaże się widok Momosa - niepoważnego, wygnanego z Olimpu starca z laską błazna u boku.

${ }^{47}$ Do tej pory zajmowałem się współczesnym pozytywizmem prawniczym, a moje badania zwieńczyła książka pt. Konwencja u podstaw prawa. Kontrowersje pozytywizmu prawniczego, Warszawa 2013. Niniejsze opracowanie natomiast otwiera nowy etap badań poświęconych pragmatyzmowi prawnemu. Na mocy własnych założeń pragmatyzmu poglądy, do których doszedłem we wcześniejszych badaniach, zostaną poddane testowi: przyszłość pokaże, co z przeszłości będzie można ocalić. 